\title{
Keragaan dan Kualitas Tanaman Pepaya Genotipe IPB 11 (Carica papaya L.) di Dataran Rendah dan Dataran Tinggi
}

\author{
Performance and Quality of Papaya IPB 11 Genotype (Carica papaya L.) \\ in the Lowland and Highland
}

Fajrilla Akhirta Marsya ${ }^{2}$, M. Rahmad Suhartanto ${ }^{12}$, Endah Retno Palupi ${ }^{12}$, Sulassih ${ }^{1}$

\begin{abstract}
${ }^{1)}$ Center for Tropical Horticulture Studies, Bogor Agicultural University, Jl Pajajaran Baranangsiang, Bogor, Indonesia ${ }^{2)}$ Department of Agonomy and Horticulture, Faculty of Agiculture at Bogor Agicultural University and Center for Tropical Horticulture Studies, Bogor Agicultural University, J1 Pajajaran Baranangsiang, Bogor, Indonesia
\end{abstract}

Diterima 20 November 2017/Disetujui 8 Januari 2018

\begin{abstract}
The aim of this research was to compare plant performance, fruit and seed quality of papaya IPB 11 genotype planted in the lowland $(261 \mathrm{~m}$ asl) and highland $(1090 \mathrm{~m}$ asl). The research was conducted from January to April 2017. The planting of papaya is located in the Pasir Kuda for low land and Pasir Sarongge for highland. Observation of fruit performance and fruit chemical quality was conducted at Postharvest Laboratory of PKHT. Testing of seed quality was conducted at screen house of Leuwikopo. Plant performance was observed on 9 plants, where as fruit performance and chemical quality was observed on 3 fruit sampels per plant. Seed quality analysis was carried out on 9 replication, 50 seeds per replication. Research data was analyzed using T test.The results showed that papaya IPB 11 genotypes planted in Pasir Sarongge had larger stem size, more number of leaves, more number of fruit, larger fruit size, and higher edible portion. Fruit of papaya IPB 11 genotype planted in Pasir Kuda has higher PTT content and has higher seed viability than in Pasir Sarongge Experimental Garden.
\end{abstract}

Key words: fruit, quality, seed, viability, vigor

\section{ABSTRAK}

Penelitian ini bertujuan membandingkan keragaan tanaman, kualitas buah, dan benih pepaya genotipe IPB 11 yang ditanam di dataran rendah $(263 \mathrm{~m} \mathrm{dpl})$ dan dataran tinggi $(1090 \mathrm{~m}$ dpl). Penelitian dilaksanakan pada bulan Januari sampai April 2017. Penanaman pepaya bertempat di Kebun Percobaan Pasir Kuda untuk lokasi dataran rendah dan Kebun Percobaan Pasir Sarongge untuk lokasi dataran tinggi. Pengamatan keragaan dan mutu kimia buah dilakukan di Laboratorium Pasca Panen PKHT. Pengujian mutu benih dilakukan di rumah kasa Kebun Percobaan Leuwikopo. Jumlah sampel untuk pengamatan keragaan tanaman sebanyak 9 tanaman dan setiap tanaman diambil 3 sampel buah untuk pengamatan keragaan dan mutu kimia buah. Pengujian mutu benih diambil sebanyak 9 ulangan dan setiap ulangan ditanam 50 butir benih. Data penelitian dianalisis menggunakan uji T. Hasil penelitian menunjukkan bahwa pepaya genotipe IPB 11 yang ditanam di KP Pasir Sarongge memiliki ukuran batang lebih besar, jumlah daun lebih banyak, jumlah buah lebih banyak, ukuran buah lebih besar, dan bagian yang dapat dimakan lebih banyak. Buah pepaya genotipe IPB 11 yang ditanam di KP Pasir Kuda memiliki kandungan PTT yang lebih tinggi dan memiliki viabilitas benih yang lebih baik daripada di KP Pasir Sarongge.

Kata kunci: benih, buah, kualitas, viabilitas, vigor

\section{PENDAHULUAN}

Buah pepaya (Carica papaya L.) merupakan salah satu buah tropis yang mempunyai nilai ekonomi dan diminati oleh konsumen. Pepaya memiliki banyak manfaat serta dapat dikonsumsi dalam bentuk segar maupun olahan. Buah pepaya sebagai sumber vitamin $\mathrm{C}$ yang baik dan memiliki kandungan nutrisi lain yang tinggi seperti kalsium,

\footnotetext{
* Penulis untuk korespondensi. e-mail: tantosuhartanto63@gmail. com
}

magnesium, posfor, zat besi, niacin, tiamin, riboflavin dan beta karoten (Nwofia dan Ojimelukwe 2012).

Indonesia merupakan negara produsen pepaya ke-3 di dunia setelah India dan Brazil (FAO 2013). Berdasarkan data BPS (2015) produksi buah pepaya pada tahun 2010 mencapai 675,801 ton, kemudian pada tahun 2011 produksinya meningkat menjadi 958,251 ton dan pada tahun 2012 produksinya menurun menjadi 906,312 ton. Pada tahun 2013 produksi buah pepaya sedikit meningkat menjadi 909,827 ton namun pada tahun 2014 dan 2015 produksinya mengalami penurunan masing-masing menjadi 840,121 ton dan 851,532 ton. Produksi pepaya masih 
mengalami fluktuasi sehingga menjadi salah satu kendala dalam pemenuhan permintaan konsumen.

Perbedaan lokasi penanaman dapat mempengaruhi pertumbuhan dan kualitas tanaman. Ketinggian tempat yang berbeda mempunyai cuaca dan iklim yang berbeda seperti suhu harian, intensitas cahaya, kelembaban, curah hujan, dan lain-lain. Hasil penelitian Afandi et al. (2013) menunjukkan bahwa melon yang ditanam pada tiga ketinggian tempat berbeda memiliki perbedaan jumlah buah, kadar gula buah, warna daging buah, tekstur daging buah, dan bobot buah per tanaman. Penelitian Deliana (2004) menyatakan bahwa buah pisang yang dipanen dari ketinggian tempat \pm 450 m dpl memiliki umur simpan yang lebih lama (25 hari) dibandingkan dengan pisang yang dipanen dari ketinggian tempat $600-990 \mathrm{~m} \mathrm{dpl} \mathrm{yaitu} \mathrm{dengan} \mathrm{umur} \mathrm{simpan} 19$ hari.

Tanaman pepaya pada umumnya ditanam pada daerah yang memiliki ketinggian 0-700 m dpl. Informasi mengenai keragaan dan kualitas tanaman pepaya yang ditanam pada ketinggian di atas $700 \mathrm{~m}$ dpl masih kurang. Oleh karena itu, perlu dipelajari mengenai keragaan dan kualitas tanaman pepaya yang ditanam pada lokasi berbeda ketinggian. Penggunaan pepaya genotipe IPB 11 pada penelitian ini karena pepaya genotipe IPB 11 belum banyak dikembangkan sehingga hasil penelitian ini dapat menambah informasi tentang mutu buah dan benih pepaya yang sudah ada sebelumnya dan dapat menambah keragaman pepaya yang membuat konsumen mempunyai banyak pilihan untuk konsumsi sesuai dengan kesukaannya.

Penelitian ini bertujuan membandingkan keragaan tanaman, kualitas buah, dan benih pepaya genotipe IPB 11 yang ditanam di dataran rendah $( \pm 263 \mathrm{~m} \mathrm{dpl})$ dan dataran tinggi $( \pm 1090 \mathrm{~m} \mathrm{dpl})$.

\section{BAHAN DAN METODE}

Penelitian dilaksanakan pada bulan Januari sampai April 2017. Penanaman pepaya bertempat di Kebun Percobaan Pasir Kuda untuk lokasi dataran rendah dan Kebun Percobaan Pasir Sarongge untuk lokasi dataran tinggi. Pengamatan keragaan tanaman dilakukan di masing-masing lokasi kebun. Laboratorium Pasca Panen PKHT sebagai tempat pengamatan keragaan buah dan mutu kimia buah pepaya serta Rumah Kasa Kebun Percobaan Leuwikopo IPB sebagai tempat pengujian mutu benih pepaya.

Bahan yang digunakan pada penelitian adalah tanaman dan buah pepaya genotipe IPB 11 berumur 11 bulan setelah tanam (BST) yang dibudidayakan oleh PKHT (Pusat Kajian Hortikultura Tropika) IPB, pasir sebagai media perkecambahan, dan larutan $\mathrm{KNO}_{3}$ sebagai bahan perlakuan standar pra-perkecambahan. Alat yang digunakan pada penelitian antara lain timbangan, jangka sorong, hand refractrometer ATAGO untuk mengukur padatan terlarut total, buret, statif, dan tray untuk tempat perkecambahan.

Penelitian terdiri atas dua tahap. Tahap 1 yaitu pengamatan keragaan tanaman, keragaan buah, dan mutu kimia buah. Pengambilan sampel untuk pengamatan keragaan tanaman sebanyak 9 tanaman sebagai ulangan dari 40 tanaman pepaya di Kebun Percobaan Pasir Kuda dan 9 tanaman sebagai ulangan dari 19 tanaman pepaya di Kebun Percobaan Pasir Sarongge. Tanaman dipilih secara acak dengan kriteria yaitu tanaman hermaprodit yang tumbuh sehat, tumbuh normal, dan buah lebih banyak. Setiap tanaman diambil 3 sampel buah yang sudah $50 \%$ kuning untuk pengamatan keragaan dan mutu kimia buah. Parameter pengamatan keragaan tanaman antara lain tinggi tanaman, diameter batang, keliling batang, jumlah daun, panjang daun, lebar daun, jumlah buah, panjang petiol, dan diameter petiol. Parameter pengamatan keragaan buah antara lain panjang buah, keliling buah, diameter buah, nisbah panjang/diameter, bobot buah, bobot kulit buah, tebal kulit buah, bobot daging buah, tebal daging buah, diameter rongga buah, dan edible portion. Parameter pengamatan mutu kimia buah yaitu padatan terlarut total (PTT), total asam tertitrasi (TAT), dan vitamin C. Tahap 2 yaitu pengujian mutu benih. Benih dari masing-masing kebun dilakukan pengujian mutu benih sebanyak 9 ulangan dan setiap ulangan ditanam 50 butir benih. Pengujian dilakukan pada media pasir dengan menggunakan tray dan ditempatkan di dalam rumah kasa. Parameter pengamatan mutu benih yaitu kadar air setelah pengeringan, daya berkecambah, potensi tumbuh maksimum, kecepatan tumbuh, indeks vigor, bobot biji basah/buah, dan bobot 1000 butir.

Analisis data dilakukan dengan menggunakan program komputer Statistical Analysis System (SAS). Analisis data menggunakan Uji $\mathrm{T}$ pada taraf $5 \%$. Uji $\mathrm{T}$ bertujuan membandingkan beda nilai tengah hasil pengamatan dari dua lokasi kebun percobaan.

\section{HASIL DAN PEMBAHASAN}

\section{Kondisi Umum}

KP Pasir Sarongge dan Pasir Kuda berada pada ketinggian yang berbeda. KP Pasir Sarongge berada pada ketinggian $\pm 1090 \mathrm{~m}$ dpl sedangkan KP Pasir Kuda pada ketinggian $\pm 263 \mathrm{~m}$ dpl. Curah hujan rata-rata di KP Pasir Sarongge mencapai $401.4 \mathrm{~mm} /$ bulan dengan suhu udara rata-rata $21.4{ }^{\circ} \mathrm{C}$ dan kelembaban udara sebesar $87 \%$. Curah hujan di KP Pasir Kuda mencapai $343.1 \mathrm{~mm} / \mathrm{bulan}$ dengan suhu udara rata-rata $26.1{ }^{\circ} \mathrm{C}$ dan kelembaban udara sebesar 85.2\%. KP Pasir Sarongge memiliki curah hujan dan kelembaban yang lebih tinggi serta suhu udara yang lebih rendah dibandingkan dengan KP Pasir Kuda. Hasil analisis tanah yang diambil saat tanaman berumur 11 BST menunjukkan kandungan hara $\mathrm{N}, \mathrm{P}$ tersedia, $\mathrm{K}$, dan $\mathrm{Mg}$ di KP Pasir Sarongge lebih tinggi daripada di KP Pasir Kuda.

Penanaman pepaya baik di KP Pasir Sarongge maupun di KP Pasir Kuda dilakukan dengan budidaya yang sama. Umur tanaman antara pepaya di KP Pasir Kuda dan Pasir Sarongge berjarak dua minggu. Pepaya di KP Pasir Kuda ditanam lebih awal daripada di KP Pasir Sarongge. Pepaya di kedua kebun ditanam pada jarak tanam $2.5 \mathrm{~m}$ x $2.5 \mathrm{~m}$. Populasi tanaman pepaya di KP Pasir Sarongge sebanyak 19 tanaman sedangkan KP Pasir Kuda sebanyak 40 tanaman. Kondisi KP Pasir Sarongge kurang terpelihara sehingga gulma yang tumbuh lebih banyak dari pada di 
KP Pasir Kuda yang terlihat lebih bersih dari gulma. Buah pada tanaman pepaya di KP Pasir Sarongge terdapat bercakbercak hitam yang diduga terserang penyakit antraknosa. Penyakit antraknosa menyerang buah menjelang masak. Penyakit antraknosa disebabkan oleh jamur Colletotrichum gleosporiades. Pada tanaman pepaya di KP Pasir Kuda tidak ditemukan serangan hama ataupun penyakit.

\section{Keragaan Tanaman Pepaya Genotipe IPB 11}

Hasil pengamatan menunjukkan terdapat perbedaan keragaan tanaman antara pepaya genotipe IPB 11 yang ditanam di KP Pasir Kuda dan Pasir Sarongge (Tabel 1). Perbedaan keragaan terlihat pada parameter diameter batang, keliling batang, jumlah daun, jumlah buah, dan diameter petiol. Parameter tinggi tanaman, panjang daun, lebar daun, dan panjang petiol tidak menunjukkan perbedaan antara tanaman pepaya di KP Pasir Kuda dan Pasir Sarongge.

Pepaya genotipe IPB 11 yang ditanam di KP Pasir Sarongge memiliki jumlah buah yang lebih banyak daripada di KP Pasir Kuda. Jumlah buah yang lebih banyak di KP Pasir Sarongge diduga disebabkan oleh produksi bunga serta keberhasilan penyerbukan yang lebih tinggi daripada di KP Pasir Kuda. Produksi bunga dapat dipengaruhi oleh ketersediaan unsur hara P. Hasil analisis tanah menunjukkan kandungan hara P di KP Pasir Sarongge lebih tinggi daripada KP Pasir Kuda. Kandungan hara P yang lebih tinggi di KP Pasir Sarongge menyebabkan produksi bunga lebih tinggi sehingga jumlah buah yang dihasilkan juga lebih banyak. Hasil penelitian Pramono (2004) menunjukkan bahwa peningkatan dosis $\mathrm{P}$ dapat meningkatkan jumlah bunga yang dihasilkan pada pepaya IPB 1.

Tanaman pepaya genotipe IPB 11 memiliki perbedaan jumlah daun dan ukuran diameter petiol antara tanaman di KP Pasir Kuda dan Pasir Sarongge. Tanaman pepaya di KP Pasir Sarongge memiliki petiol warna ungu sedangkan di KP Pasir Kuda warna hijau. Tanaman pepaya di KP Pasir Sarongge memiliki jumlah daun lebih banyak serta ukuran diameter petiol lebih besar daripada di KP Pasir Kuda. Meskipun terdapat perbedaan jumlah daun, ukuran daun dari tanaman pepaya genotipe IPB 11 di kedua kebun tidak berbeda dapat dilihat dari ukuran panjang dan lebar daunnya yang sama. Panjang petiol juga tidak berbeda antara tanaman pepaya genotipe IPB 11 di KP Pasir Kuda dan Pasir Sarongge.

\section{Keragaan Buah Pepaya Genotipe IPB 11}

Hasil pengamatan menunjukkan terdapat perbedaan keragaan buah antara pepaya genotipe IPB 11 yang ditanam di KP Pasir Kuda dan Pasir Sarongge. Perbedaan keragaan buah terlihat hampir pada semua parameter pengamatan yaitu panjang buah, diameter buah, keliling buah, nisbah panjang/ diameter, bobot buah, bobot kulit buah, tebal kulit buah, bobot daging buah, tebal daging buah, diameter rongga buah, dan edible portion. Daging buah yang dihasilkan pepaya dari KP Pasir Kuda berwarna jingga terang sedangkan dari KP Pasir Sarongge berwarna jingga pucat. Keragaan buah pepaya genotipe IPB 11 tidak menunjukkan perbedaan pada parameter tebal kulit dan bobot kulit (Tabel 2).

Panjang, keliling, dan diameter buah pepaya genotipe IPB 11 berbeda antara yang ditanam di KP Pasir Kuda dan Pasir Sarongge. Penanaman pepaya genotipe IPB 11 di KP Pasir Sarongge menghasilkan buah pepaya berukuran lebih besar daripada KP Pasir Kuda. Curah hujan yang lebih tinggi di KP Pasir Sarongge menyebabkan ketersediaan air pada tanaman di KP Pasir Sarongge lebih baik daripada di KP Pasir Kuda. Ketersediaan air yang lebih baik di KP Pasir Sarongge menyebabkan fotosintat yang dihasilkan dari proses fotosintesis lebih banyak. Fotosintat yang dihasilkan oleh tanaman pepaya di KP Pasir Sarongge lebih banyak diduga menyebabkan ukuran buah yang dihasilkan

Tabel 1. Hasil pengamatan keragaan tanaman pepaya genotipe IPB 11 di dua kebun percobaan

\begin{tabular}{lccc}
\hline \multicolumn{1}{c}{ Parameter } & \multicolumn{2}{c}{ Rata-rata } & \multirow{2}{*}{ t-hitung } \\
\cline { 2 - 3 } Tinggi tanaman $(\mathrm{cm})$ & KP Pasir Kuda & KP Pasir Sarongge & -0.36 tn \\
Diameter batang $(\mathrm{cm})$ & $224.56 \pm 29.60$ & $228.33 \pm 10.30$ & $-5.25 * *$ \\
Keliling batang $(\mathrm{cm})$ & $10.81 \pm 1.30$ & $14.29 \pm 1.50$ & $-6.77 * *$ \\
Jumlah buah & $38.44 \pm 5.46$ & $53.78 \pm 4.06$ & $-3.39 * *$ \\
Jumlah daun & $76.78 \pm 17.53$ & $105.44 \pm 18.32$ & $-7.43 * *$ \\
Panjang daun $(\mathrm{cm})$ & $34.11 \pm 4.83$ & $51.89 \pm 5.30$ & -2.1 tn \\
Lebar daun $(\mathrm{cm})$ & $35.11 \pm 3.98$ & $38.56 \pm 2.88$ & -0.55 tn \\
Panjang petiol $(\mathrm{cm})$ & $57.11 \pm 6.49$ & $58.44 \pm 3.21$ & -0.4 tn \\
Diameter petiol pangkal $(\mathrm{cm})$ & $77.89 \pm 9.06$ & $79.33 \pm 5.87$ & $-8.46 * *$ \\
Diameter petiol tengah $(\mathrm{cm})$ & $2.14 \pm 0.30$ & $3.53 \pm 0.39$ & $-2.96 *$ \\
Diameter petiol ujung $(\mathrm{cm})$ & $1.34 \pm 0.22$ & $1.59 \pm 0.11$ & $-3.79 * *$ \\
\hline
\end{tabular}

Keterangan: tn, $* * *=$ berturut-turut hasil uji-t tidak nyata pada taraf $5 \%$, nyata pada taraf $5 \%$ dan nyata pada taraf $1 \%$ 
lebih besar daripada di KP Pasir Kuda. Lakitan (2011) menyatakan bahwa air merupakan substrat yang dibutuhkan untuk fotosintesis, kekurangan air menyebabkan stomata menutup sehingga menghambat serapan $\mathrm{CO}_{2}$.

Nisbah antara panjang terhadap diameter buah menunjukkan perbedaan. Buah yang berasal dari KP Pasir Sarongge memiliki nisbah panjang/diameter lebih besar daripada buah dari KP Pasir Kuda berkisar 2.2-2.3 sehingga buah pepaya genotipe IPB 11 baik yang ditanam di KP Pasir Kuda maupun di Pasir Sarongge tergolong pada buah berbentuk lonjong. Suketi et al.(2010a) menyatakan bahwa buah pepaya hermaprodit cenderung berbentuk lonjong dengan nisbah panjang/diameter buah berkisar 1.5-2.3.

Buah hasil panen dari KP Pasir Sarongge memiliki bobot buah, bobot daging buah, tebal daging buah, dan diameter rongga buah yang lebih besar dibandingkan dengan buah hasil panen dari KP Pasir Kuda. Buah pepaya genotipe IPB 11 berdasarkan bobot buahnya baik yang berasal dari KP Pasir Kuda maupun Pasir Sarongge digolongkan ke dalam pepaya tipe kecil karena memiliki bobot buah berkisar 451.82-496.68 g. Sujiprihati dan Suketi (2009) menyatakan buah pepaya yang memiliki bobot buah kurang dari $750 \mathrm{~g}$ tergolong pada pepaya tipe kecil.

Edible portion menunjukkan persentase bagian buah yang dapat dimakan. Edible portion buah yang berasal dari KP Pasir Sarongge lebih besar daripada buah dari KP Pasir Kuda. Menurut Suketi et al. (2010b) penentuan edible portion bersifat subjektif tergantung konsumen dalam memanfaatkan bagian buah pepaya untuk dikonsumsi baik dalam bentuk segar maupun olahan. Hasil pengamatan pada tabel 2 menunjukkan semakin tebal daging buah maka bobot daging buah dan edible portion cenderung semakin besar pula. Menurut Budiyanti et al. (2005) semakin makin tebal daging buah maka semakin banyak bagian buah pepaya yang dapat dikonsumsi. Nakasone dan Paull (1998) menyatakan tebal daging buah pepaya berkisar antara $1.5-4 \mathrm{~cm}$.

\section{Mutu Kimia Buah Pepaya Genotipe IPB 11}

Mutu kimia mempengaruhi kualitas pepaya. Perubahan komposisi kimia terjadi seiring dengan pematangan buah. Mutu kimia mempengaruhi kualitas rasa dan kandungan gizi buah. Hasil pengamatan menunjukkan terdapat perbedaan mutu kimia buah antara pepaya genotipe IPB 11 yang ditanam di KP Pasir Kuda dan Pasir Sarongge. Perbedaan mutu kimia buah terlihat pada parameter padatan terlarut total (PTT), total asam tertitrasi (TAT), vitamin C dan (Tabel 3).

Kandungan PTT buah yang berasal dari KP Pasir Kuda sebesar $15.22{ }^{\circ}$ Brix sedangkan buah di KP Pasir Sarongge sebesar $8.89^{\circ}$ Brix. Semakin tinggi nilai PTT maka kemanisan buah semakin meningkat.Tingkat kemanisan buah yang ditanam di KP Pasir Sarongge masih rendah sedangkan pada buah yang ditanam di KP Pasir Kuda sudah tinggi. Nilai Padatan terlarut total yang dikehendaki oleh konsumen berkisar 11-13 ${ }^{\circ}$ Brix (Saryoko et al. 2004). Buah pepaya genotipe IPB 11 yang berasal dari KP Pasir Kuda memiliki kandungan asam lebih rendah daripada di KP Pasir Sarongge. Nilai TAT buah yang ditanam di KP Pasir Kuda sebesar 1.06 \% sedangkan di KP Pasir Sarongge sebesar 1.48 \%. Rasio PTT/ATT merupakan perbandingan nilai gula dan asam yang terkandung dalam buah. Hasil pengamatan pada tabel 3 menunjukkan bahwa semakin tinggi kandungan PTT maka kandungan TAT cenderung berkurang sebaliknya semakin rendah kandungan PTT maka kandungan TAT meningkat. Buah pepaya di KP Pasir Kuda memiliki rasio PTT/TAT sebesar 16.45 sedangan buah di KP Pasir Sarongge sebesar 6.19. Semakin tinggi rasio PTT/ TAT maka kemanisan buah juga semakin tinggi. Winarno dan Aman (1981) menyatakan selama proses pematangan buah klimakterik terjadi peningkatan kandungan gula tetapi kandungan asamnya menurun sehingga rasio gula dan asam akan mengalami perubahan yang drastis.

Tabel 2. Hasil pengamatan keragaan buah pepaya genotipe IPB 11 di dua kebun percobaan

\begin{tabular}{lccc}
\hline \multirow{2}{*}{\multicolumn{1}{c}{ Parameter }} & \multicolumn{2}{c}{ Rata-rata } & \multirow{2}{*}{ t-hitung } \\
\cline { 2 - 3 } & KP Pasir Kuda & KP Pasir Sarongge & $-4.72 * *$ \\
\hline Panjang buah $(\mathrm{cm})$ & $17.43 \pm 0.70$ & $18.99 \pm 0.70$ & $-2.16 *$ \\
Diameter buah $(\mathrm{cm})$ & $7.96 \pm 0.31$ & $8.29 \pm 0.34$ & $-3.3 * *$ \\
Keliling buah $(\mathrm{cm})$ & $26.17 \pm 0.70$ & $27.58 \pm 1.07$ & $-2.27 *$ \\
Nisbah panjang/diameter & $2.2 \pm 0.09$ & $2.3 \pm 0.10$ & $-2.21 *$ \\
Bobot buah $(\mathrm{g})$ & $451.82 \pm 50.39$ & $496.68 \pm 34.20$ & $0.86 \mathrm{tn}$ \\
Bobot kulit buah $(\mathrm{g})$ & $126.88 \pm 16.75$ & $120.61 \pm 13.97$ & $1.41 \mathrm{tn}$ \\
Tebal kulit buah $(\mathrm{cm})$ & $0.36 \pm 0.07$ & $0.31 \pm 0.06$ & $-4.56 * *$ \\
Bobot daging buah $(\mathrm{g})$ & $285.52 \pm 32.67$ & $344.15 \pm 20.54$ & $-5.25 * *$ \\
Tebal daging buah $(\mathrm{cm})$ & $2.03 \pm 0.16$ & $2.42 \pm 0.16$ & $-4.38 * *$ \\
Diameter rongga buah $(\mathrm{cm})$ & $4.1 \pm 0.21$ & $4.68 \pm 0.34$ & $-5.48 * *$ \\
Edible portion $(\%)$ & $63.18 \pm 2.47$ & $69.29 \pm 2.25$ &
\end{tabular}

Keterangan: $\mathrm{tn}, * * *=$ berturut-turut hasil uji-t tidak nyata pada taraf $5 \%$, nyata pada taraf $5 \%$ dan nyata pada taraf $1 \%$ 
Perbedaan suhu antara KP Pasir Kuda dan Pasir Sarongge mempengaruhi mutu kimia buah yang dihasilkan. Suhu berkaitan dengan satuan panas yang diterima tanaman. Perbedaan satuan panas antara buah pepaya genotipe IPB 11 di KP Pasir Kuda dan Pasir Sarongge saat melakukan pengamatan menyebabkan mutu kimia yang dihasilkan berbeda. KP Pasir Kuda memiliki suhu udara yang lebih tinggi sehingga diduga memiliki satuan panas yang lebih tinggi daripada di KP Pasir Sarongge. Hasil penelitian Nora (2017) menunjukkan bahwa buah pepaya Callina yang dipanen pada satuan panas yang lebih tinggi menghasilkan buah dengan kandungan PTT yang lebih tinggi daripada buah yang dipanen pada satuan panas lebih rendah.

Kandungan vitamin $\mathrm{C}$ buah hasil panen dari KP Percobaan Pasir Sarongge sebesar $17.28 \mathrm{mg} / 100$ g sedangkan buah hasil panen di KP Pasir Kuda memiliki kandungan vitamin C sebesar $9.07 \mathrm{mg} / 100 \mathrm{~g}$. Hasil pengamatan ini menunjukkan bahwa penanaman pepaya genotipe IPB $11 \mathrm{di}$ KP Pasir Sarongge yang memiliki ketinggian lebih tinggi, suhu udara lebih rendah serta curah hujan lebih tinggi menghasilkan buah dengan kandungan vitamin $\mathrm{C}$ yang lebih tinggi dari pada penanaman pepaya di KP Pasir Kuda. Kandungan vitamin $\mathrm{C}$ dapat dipengaruhi oleh faktor seperti lama penyinaran dan suhu lingkungan (Lee dan Kader 2000). Hasil penelitian Fatchurrozak (2013) menunjukkan kandungan vitamin $\mathrm{C}$ pada buah karika (Carica pubescens) semakin tinggi seiring bertambahnya ketinggian tempat, seperti pepaya genotipe IPB 11 di KP Pasir Sarongge

\section{Mutu Benih Pepaya Genotipe IPB 11}

Mutu benih yang diamati adalah mutu benih setelah panen dan belum dilakukan penyimpanan. Hasil pengamatan menunjukkan bahwa terdapat perbedaan mutu benih antara pepaya genotipe IPB 11 yang ditanam di KP Pasir Kuda dan Pasir Sarongge. Perbedaan mutu benih terlihat pada parameter daya berkecambah (DB), potensi tumbuh maksimum (PTM), indeks vigor (IV), kecepatan tumbuh (KcT), bobot biji basah/buah dan bobot 1000 butir (Tabel 4). Kadar air benih penting diketahui. Kadar air dapat memprediksi kemunduran suatu benih, dalam batas tertentu kadar air yang semakin rendah dapat memperpanjang daya hidup benih sebaliknya kadar air yang tinggi dapat menyebabkan benih berkecambah sebelum ditanam (Sutopo 2010). Menurut Sari (2005) benih pepaya IPB-1 tanpa sarcotesta mampu mempertahankan viabilitasnya hingga kadar air benih 6-7\% dan tidak berbeda nyata dengan benih dengan kadar air 11-12\%. Penurunan hingga kadar air yang relatif rendah akan sangat bermanfaat untuk menekan laju metabolisme dan diharapkan dapat menekan laju kemunduran benih. Kadar air benih setelah pengeringan dari kedua kebun tidak berbeda yaitu sebesar $8.8 \%$. Benih yang berasal dari buah di KP Pasir Kuda pada kadar air $8.8 \%$ memiliki bobot 1000 butir lebih tinggi dari pada benih dari buah di KP Pasir Sarongge dan lebih bernas. Bobot biji basah per buah dari KP Pasir Kuda juga lebih tinggi dari pada di KP Pasir Sarongge.

Tabel 3. Hasil uji kandungan kimia buah pepaya genotipe IPB 11 di dua kebun percobaan

\begin{tabular}{|c|c|c|c|}
\hline \multirow{2}{*}{ Parameter } & \multicolumn{2}{|c|}{ Rata-rata } & \multirow{2}{*}{ t-hitung } \\
\hline & KP Pasir Kuda & KP Pasir Sarongge & \\
\hline PTT ( ${ }^{\circ}$ Brix $)$ & $15.22 \pm 0.44$ & $8.89 \pm 0.64$ & $24.52 * *$ \\
\hline TAT $(\%)$ & $1.06 \pm 0.23$ & $1.48 \pm 0.12$ & $-4.82 * *$ \\
\hline PTT/TAT & $16.45 \pm 2.46$ & $6.19 \pm 0.68$ & $12.06 * *$ \\
\hline Vitamin $C(\mathrm{mg} / 100 \mathrm{~g})$ & $9.07 \pm 1.52$ & $17.28 \pm 2.62$ & $-8.13 * *$ \\
\hline
\end{tabular}

Keterangan: $\mathrm{tn}, *, * *=$ berturut-turut hasil uji-t tidak nyata pada taraf $5 \%$, nyata pada taraf $5 \%$ dan nyata pada taraf $1 \%$

Tabel 4. Hasil uji mutu benih pepaya genotipe IPB 11 di dua kebun percobaan

\begin{tabular}{lccc}
\hline \multirow{2}{*}{\multicolumn{1}{c}{ Parameter }} & \multicolumn{2}{c}{ Rata-rata } & \multirow{2}{*}{ t-hitung } \\
\cline { 2 - 3 } & KP Pasir Kuda & KP Pasir Sarongge & \\
\hline Kadar air setelah pengeringan (\%) & $8.89 \pm 0.23$ & $8.88 \pm 0.26$ & 0.1 tn \\
Bobot biji basah/buah (g) & $39.44 \pm 7.26$ & $31.91 \pm 5.80$ & $2.42 *$ \\
Bobot 1000 butir (g) & $23.22 \pm 0.77$ & $21.95 \pm 0.90$ & $3.25 * *$ \\
Daya berkecambah (\%) & $79.33 \pm 5.20$ & $67.33 \pm 11.83$ & $2.79 *$ \\
Potensi tumbuh maksimum (\%) & $80 \pm 4.90$ & $68.22 \pm 13.54$ & $2.45^{*}$ \\
Indeks vigor (\%) & $71.56 \pm 4.88$ & $41.56 \pm 15.22$ & $5.63 * *$ \\
Kecepatan tumbuh (\%/etmal) & $7.08 \pm 0.54$ & $4.76 \pm 1.05$ & $5.9 * *$ \\
\hline
\end{tabular}

Keterangan: $\operatorname{tn}, * * *=$ berturut-turut hasil uji-t tidak nyata pada taraf $5 \%$, nyata pada taraf $5 \%$ dan nyata pada taraf $1 \%$ 
Benih yang berasal dari tanaman pepaya di KP Pasir Kuda memiliki viabilitas dan vigor yang lebih baik dari pada benih yang berasal dari KP Pasir Sarongge. Daya berkecambah benih yang berasal dari KP Pasir Kuda sebesar 79.33\% dengan potensi tumbuh maksimum sebesar $80 \%$ sedangkan benih yang berasal dari KP Pasir Sarongge memiliki daya berkecambah sebesar $67.33 \%$ dan potensi tumbuh maksimum sebesar 68.22\%. Daya berkecambah benih yang dihasilkan buah dari KP Pasir Kuda lebih tinggi daripada KP Pasir Sarongge. Benih yang baik adalah benih yang memiliki daya berkecambah lebih tinggi. Semakin tinggi daya berkecambah benih dapat mengurangi persentase benih yang tidak tumbuh di lapang. Kecepatan tumbuh benih yang berasal dari KP Pasir Kuda sebesar 7.08\% etmal ${ }^{-1}$ dengan indeks vigor $71.56 \%$ sedangkan benih dari KP Pasir Sarongge kecepatan tumbuhnya sebesar $4.76 \%$ etmal $^{-1}$ dan indeks vigor $41.56 \%$. Benih yang berasal dari KP Pasir kuda lebih cepat tumbuh dan memiliki vigor yang lebih tinggi.

Perbedaan antara mutu benih dari KP Pasir Kuda dan Pasir Sarongge diduga disebabkan oleh perbedaan kemasakan buah saat panen. Perbedaan kemasakan disebabkan oleh umur tanaman dan suhu yang berbeda dari kedua kebun. Umur tanaman pepaya genotipe IPB 11 di KP Pasir Kuda lebih tua dua minggu daripada di KP Pasir Sarongge sedangkan pemanenan buah dilakukan pada saat yang sama sehingga buah dari KP Pasir Kuda lebih masak daripada buah dari KP Pasir Sarongge. KP Pasir Sarongge memiliki suhu yang lebih rendah sehingga menyebabkan umur tanaman lebih panjang dan buah yang dipanen memiliki kemasakan yang berbeda dengan buah di KP Pasir Kuda ketika dipanen pada waktu yang bersamaan. Oleh karena itu, buah dari KP Pasir Kuda memiliki mutu benih yang lebih baik daripada buah di KP Pasir Sarongge.

\section{KESIMPULAN}

Perbedaan lokasi penanaman yang memiliki perbedaan ketinggian, iklim mikro, dan kesuburan tanah menyebabkan adanya perbedaan keragaan tanaman, keragaan buah, mutu kimia buah, dan mutu benih pepaya genotipe IPB 11. Penanaman pepaya genotipe IPB 11 di KP Pasir Sarongge untuk lokasi dataran tinggi $( \pm 1090 \mathrm{~m} \mathrm{dpl})$ menghasilkan pepaya dengan ukuran batang lebih besar, jumlah daun lebih banyak, jumlah buah lebih banyak dan ukuran buah lebih besar. Sebaliknya, penanaman pepaya genotipe IPB 11 di KP Pasir Kuda untuk lokasi dataran rendah $( \pm 263 \mathrm{~m} \mathrm{dpl})$ menghasilkan pepaya dengan rasa yang lebih manis dan mutu benih yang lebih baik meskipun ukuran batang lebih kecil, jumlah daun lebih sedikit, jumlah buah lebih sedikit, dan ukuran buah lebih kecil.

\section{DAFTAR PUSTAKA}

Afandi, M.A., R. Sulistyono, N. Herlina. 2013. Respon pertumbuhan dan hasil lima varietas melon (Cucumis melo L.) pada tiga ketinggian tempat. J Prod Tan. 1(4):342-352.
[BPS] Badan Pusat Statistik. 2015. Produksi Pepaya. https:// www.bps.go.id/site/resultTab [17 Mei 2017].

Budiyanti, T., S. Purnomo, Karsinah, A. Wahyudi. 2005. Karakterisasi 88 aksesi pepaya koleksi balai penelitian tanaman buah. BulPlasma Nutfah. 11(1): 21-27.

Deliana. 2004. Kualitas buah pisang ambon putih (Musa sapientum L.) yang dipanen dari ketinggian lahan yang berbeda selama penyimpanan. Skripsi. Institut Pertanian Bogor. Bogor.

[FAO] Food and Agricultural Organization. 2013. Top 10 Country Production by Papayas. http://www.fao. org/faostat/en/\#rankings/countries_by_commodity[4 April 2017]

Fatchurroazak. 2013. Pengaruh ketinggian tempat terhadap kandungan vitamin $\mathrm{C}$ dan zat antioksidan pada buah Carica pubescens di dataran tinggi Dieng. El-vivo. 1(1):24-31.

Lakitan, B. 2011. Dasar-Dasar Fisiologi Tumbuhan. Rajawali Pres. Jakarta.

Lee, S.K., A.A. Kader. 2000. Preharvest and postharvest factors influencing vitamin content of horticultural crops. Postharvest Bio and Tech. 20:207-220.

Nakasone, H.Y., R.E. Paull. 1998. Tropical Fruits. New York (USA): CABI.

Nora, H.N. 2017. Penentuan umur petik pepaya Callina berbasis satuan panas. Skripsi. Institut Pertanian Bogor. Bogor

Nwofia, G.E., P. Ojimelukwe. 2012. Variability in proximate, mineral and vitamin contens of Carica papaya (L.) leaves, fruit pulp and seeds. Int. J. Med. Arom. Plants. 2(1):90-96.

Pramono, A. 2004. Pengaruh fosfor dan kalium terhadap pertumbuhan dan produksi pepaya (Carica papaya 1.). Skripsi. Institut Pertanian Bogor. Bogor.

Sari, M. 2005. Pengaruh sarcotesta dan kadar air benih terhadap viabilitas, kandungan total fenol dan daya simpan benih pepaya (Carica papaya L.). Tesis. Institut Pertanian Bogor. Bogor.

Saryoko, A., R. Yuniar, S. Sujiprihati, S. 2004. Karakterisasi plasma nutfah pepaya di Pusat Kajian Buah Tropika, IPB. Prosiding Simposium Nasional Peripi. Perhimpunan Ilmu Pemuliaan Indonesia dan Fakultas Pertanian, IPB. Bogor. 
Sujiprihati, S., K. Suketi. 2009. Budidaya Pepaya Unggul. Penebar Swadaya. Jakarta.

Suketi, K., R. Poerwanto, S. Sujiprihati, Sobir, W.D. Widodo. 2010a. Karakter fisik dan kimia buah pepaya pada stadia kematangan berbeda. J Agron Indonesia. 38(1):60-66.
Suketi, K., R. Poerwanto, S. Sujiprihati, Sobir, W.D. Widodo. 2010b. Studi karakter mutu buah pepaya IPB. J Hort Indonesia.1(1):17-26.

Sutopo, L. 2010. Teknologi Benih. Raja Grafindo Persada. Jakarta.

Winarno, F.G., A.W. Aman. 1981. Fisiologi Lepas Panen. Sastra Hudaya. Jakarta. 